\title{
Repellent activity of DEET against Amblyomma cajennense (Acari: Ixodidae) nymphs submitted to different laboratory bioassays
}

\author{
Atividade repelente do DEET contra ninfas de Amblyomma cajennense (Acari: Ixodidae)
} em bioensaio laboratorial

\begin{abstract}
Sara Fernandes Soares ${ }^{1 *}$; Raquel de Sousa Braga ${ }^{1}$; Lorena Lopes Ferreira ${ }^{1}$; Carla Cristina Braz Louly ${ }^{1}$; Lorena Alessandra Dias de Sousa ${ }^{1}$; Andrea Caetano da Silva ${ }^{2}$; Lígia Miranda Ferreira Borges ${ }^{2}$
\end{abstract}

${ }^{1}$ Escola de Veterinária, Universidade Federal de Goiás - UFG

${ }^{2}$ Instituto de Patologia Tropical e Saúde Pública, Universidade Federal de Goiás - UFG

Received February 04, 2009

Accepted June 30, 2009

\begin{abstract}
This study was developed to evaluate the repellent activity of N,N-diethyl-3-methylbenzamide (DEET) against Amblyomma cajennense nymphs. Two repellent bioassays were compared and the effective concentration and repellent time were calculated. The fingertip test was accomplished to evaluate in vivo four concentrations of the compound $\left(0.200 ; 0.100 ; 0.050\right.$ and $\left.0.025 \mathrm{mg} . \mathrm{cm}^{-2}\right)$ and the filter-paper bioassay to evaluate in vitro the two highest concentrations. The compound provided repellence higher than $90 \%$ in all concentrations and at least $95 \%$ repellency in the highest concentration over 5 hours. The effective concentration against $50 \%$ of tested nymphs (EC50) was $0.006 \mathrm{mg} . \mathrm{cm}^{-2}$ and the EC99 was $0.036 \mathrm{mg} \cdot \mathrm{cm}^{-2}$. Those concentrations were lower than the ones obtained against other tick species, denoting the effectiveness of DEET against $A$. cajennense. The repellency time against $50 \%$ of the ticks (RT50) was 4.8 hours and the RT90 was 2.7 hours. Both bioassays were adequate to evaluate $A$. cajennense repellency and provided similar results; however the in vivo test is more appropriate to estimate the effective concentration and repellency time.
\end{abstract}

Keywords: DEET, Amblyomma cajennense, repellency time, fingertip bioassay.

\section{Resumo}

Este estudo foi conduzido com o objetivo de avaliar a atividade repelente do N,N-diethyl-3-methylbenzamide (DEET) sobre ninfas de Amblyomma cajennense. Dois bioensaios para a avaliação de repelência foram comparados e cálculos da concentraçáo eficaz e do tempo de repelência foram realizados. Foram empregados o bioensaio da ponta do dedo, para avaliação in vivo de quatro concentaçóes do químico $\left(0,200 ; 0,100 ; 0,050\right.$ e $\left.0,025 \mathrm{mg} \cdot \mathrm{cm}^{-2}\right)$ e o bioensaio do papel filtro, para a avaliação in vitro das duas concentraçóes mais altas. O composto conferiu mais de $90 \%$ de repelência em todas as concentraçôes utilizadas e $95 \%$ de repelência por mais de cinco horas na maior concentração. A concentraçáo do composto efetiva contra 50\% das ninfas testadas (CE50) foi de 0,006 mg.cm ${ }^{-2}$ e a CE99 foi de $0,036 \mathrm{mg} \cdot \mathrm{cm}^{-2}$. Estas concentraçóes são mais baixas do que as observadas em outras espécies de carrapatos, denotando a efetividade do princípio contra $A$. cajennense. O tempo de repelência de $50 \%$ dos carrapatos (TR50) foi de 4,8 horas e o TR90 de 2,7 horas. Os dois bioensaios avaliados permitiram a observação de percentuais de repelência igualmente altos e se mostraram adequados para tal avaliação, sendo que o teste in vivo é mais indicado para cálculo da concentração eficaz e da duração da repelência.

Palavras-chave: DEET, Amblyomma cajennense, tempo de repelência, bioensaio ponta do dedo. 


\section{Introduction}

Amblyomma cajennense (Fabricius), the Cayenne tick, is a three-host species that, despite the adult's preference for equids, can parasitize other mammals such as bovids, cervids, and wild and domestic canids, as well as birds and human beings (BARROS- BATTESTI et al., 2006). It is spread over the American continent, from the Southern USA to Northern Argentina. Due to its unspecificity it is involved in the transmission of pathogens between animals and humans. It is the vector of Rickettsia rickettsii (Wolbach) Brumpt, causal agent of the Rocky Mountain Spotted Fever in Central and South America (DIAS; MARTINS, 1939; BUSTAMANTE et al., 1946; DE RODANICHE, 1953; GUEDES et al., 2005). It is also able to experimentally transmit Rickettsia parkeri Lackman et al. (SANGIONI et al., 2005), agent associated with clinical symptoms of a rickettsial fever (PADDOCK et al., 2004) and can be involved in the transmission of other rickettsial agents (BILLINGS et al., 1998).

The control of this tick is difficult due to the large variety of hosts and to the short duration of parasitic phases (LABRUNA et al., 2004). Only commercial pyrethroid formulations are recommended to treat equids. However, field and laboratory assays showed that $A$. cajennense adults are naturally resistant to this base (BITTENCOURT et al., 1987, 1989). In this context, repellents allow a different approach, whose aim is to prevent tick attachment to the hosts, reducing the use of acaricides. The World Health Organization (WHO) recommends the use of personal protection mechanisms in endemic regions against arthropod-borne diseases (BARNARD, 2000).

The compound N,N-diethyl-3-methylbenzamide, previously named N,N-diethyl-m-toluamide and popularly known as DEET (Sigma Aldrich - Sigma-Aldrich 3050 Spruce St. St. Louis, MO 63103), was patented in the Department of Agriculture by the US Army in 1946 and registered for public use in 1957 (FRADIN, 1998). It is a well-characterized compound, recognized as a reference repellent, and it has been extensively used by civilian and military personnel. Annually, over 200 million people use it for individual protection. Through the years, it has shown itself to have an outstanding safety profile and it has not been dangerous to human health nor to the environment (FRADIN, 1998). However, the National Health Surveillance Agency (Anvisa, Brazil) does not recommend it for children under two years old (ANVISA, 2006). It is a large-spectrum repellent, acting against mosquitoes, hematophagous flies, lice, fleas and ticks. Due to its outstanding role as a repellent, it has been tested against different tick species, showing activity against Amblyomma americanum Linnaeus, Ixodes ricinus Linnaeus, Amblyomma hebraeum Koch and Ixodes scapularis Say (SCHRECK et al., 1995; STAUB et al., 2002; PRETORIUS et al., 2003; CARROLL et al., 2005).

This study was developed to evaluate the repellent activity of $\mathrm{N}, \mathrm{N}$-diethyl-3-methylbenzamide (DEET) against $A$. cajennense nymphs. Two repellent bioassays were compared and the effective concentration and repellency time were calculated, proving its efficacy against $A$. cajennense.

\section{Materials and Methods}

\section{Ticks and volunteers}

A. cajennense engorged females were obtained in naturally infested equines and incubated in a chamber $\left(27^{\circ} \mathrm{C}, 80 \% \mathrm{RH}\right)$ during the oviposition period. Five-day-old larvae were placed on rabbits to feed (Oryctolagus cuniculus) using a feeding chamber (SONENSHINE, 1991). Engorged larvae were collected from the rabbits and incubated in the same conditions mentioned above. Unfed nymphs with ages varying from two weeks to two months were tested in the repellency bioassays. The bioassays were carried out on three female volunteers.

\section{Repellent bioassays}

DEET (Fluka, C12H17NO, MM 191.28, 95\% pure, lot $11706212)$ was purchased from Sigma-Aldrich. Stock solution $\left(7.2 \% \approx 0.200 \mathrm{mg} \cdot \mathrm{cm}^{-2}\right)$ was prepared using $95 \%$ ethanol as the solvent. This concentration is close to those observed in low concentrations of DEET available in commercial formulations. The following concentrations: $0.200,0.100,0.050$ and $0.025 \mathrm{mg} . \mathrm{cm}^{-2}$ diluted in ethanol $95 \%$ were used in fingertip bioassays and the two highest in filter-paper bioassays.

\section{Fingertip bioassay}

This bioassay was developed according to Schreck et al. (1995). The proximal phalange of the left index finger of one volunteer was treated with DEET and the right one with ethanol $95 \%$ as the negative control. A volume of $2.75 \mu \mathrm{L} . \mathrm{cm}^{-2}$ per treated area was used. The test was performed 10 minutes after the solution had been applied, for solvent evaporation. A nymph was released, individually, on the distal phalange, then the finger was vertically positioned with tip downward, allowing the tick to climb the finger because of its negative geotropism. The ticks that dropped off the finger, inverted their direction after touching the treated area, or remained on the release point after 1 minute were considered repelled. To evaluate the repellent time, the tests were repeated after 50 minutes and later every hour, until repellence was lower than $50 \%$. Thirty ticks were evaluated for each concentration. All nymphs were previously tested in the negative control and only the active ones were tested with DEET. One hour after the first treatment interval (10 minutes) the mortality of the tested nymphs was evaluated. To evaluate behavior alterations, the surviving nymphs were submitted to fingertip bioassay again, using DEET in the same concentration as the previous test.

\section{Filter-paper bioassay}

This bioassay was developed according to Carroll et al. (2004). A piece of filter paper $(10 \mathrm{~cm}$ long $\times 6 \mathrm{~cm}$ wide $)$ was divided into three strips of $2.2,3.3$ and $4.5 \mathrm{~cm}$ long by $6 \mathrm{~cm}$ wide. The middle strip $(3.3 \times 6 \mathrm{~cm})$ was treated with $165 \mu \mathrm{L}$ of DEET or ethanol $95 \%$ as the negative control. The filter paper was 
vertically positioned and attached in the middle of a Petri dish $(9 \mathrm{~cm}$ diameter). Five ymphs were released on the lower strip and their movements were evaluated during 5 minutes. The evaluation of repellency and the repellency time were estimated similarly as mentioned above in the fingertip bioassay. Ten repetitions were done for each concentration. All nymphs were previously tested in the negative control and only the active ones were tested with DEET.

\section{Statistical analysis}

The comparisons among the concentrations and the bioassays were done by the chi-square test using a significance level of $p<0.05$. When the percentage of repellency was significantly higher than in the control, that concentration was considered as repellent. The estimate of effective concentrations (EC) and repellency time (RT) against 50, 90, 95 and 99\% of tested nymphs (EC50, EC90, EC95, EC99 and RT50, RT90, RT95 and RT99) were done by probit analysis (Priprobit Copyright - C 1996-2000. Masayuki Sakumo - All rights reserved. Ver 1.63), using the results obtained in fingertip bioassay.

\section{Results}

\section{Fingertip bioassay}

A. cajennense nymphs were repelled in all tested concentrations. Even in the lowest concentration high percentages of repellency were obtained; however, after one hour of observation, there was a significant decrease in repellency. At the 0.200 and $0.100 \mathrm{mg} . \mathrm{cm}^{-2}$ concentrations, the first repellency rates were 100\%, and they were near $97 \%$ up to 4 hours in the higher concentration. Even after 5 hours, the observed repellency observed was significantly different from the ethanolic control at $0.200 \mathrm{mg} \cdot \mathrm{cm}^{-2}$. The reduction of DEET concentration interfered mainly in the repellency duration (Table 1).

The EC50, EC90, EC95 and EC99 in the first hour were $0.006,0.025,0.036$ and $0.075 \mathrm{mg} . \mathrm{cm}^{-2}$, respectively. The RT50 at $0.200 \mathrm{mg} \cdot \mathrm{cm}^{-2}$ concentration was nearly 5 hours and the RT90 in the same concentration was 1 hour 41 minutes. The RTs decreased with the reduction of the concentration (Figure 1) and at $0.025 \mathrm{mg} \cdot \mathrm{cm}^{-2}$ the RT99 was 0.1 hour (= 6 minutes).

Nearly $30 \%$ of the ticks tested in the two highest concentrations died 1 hour after the test. All ticks which came in contact with the finger-treated area, even the ones that were not repelled, exhibited behavior alterations, such as locomotion with large and slow steps trying to keep their bodies away from the repellent.

\section{Comparison between bioassays}

Significant difference between the tests was observed only after 5 hours, in the $0.200 \mathrm{mg} \cdot \mathrm{cm}^{-2}$ concentration, with rates of 100 and 33\% in filter-paper and fingertip, respectively. In this concentration, in the filter-paper test an expressive decrease in the repellence rate was observed only 20 hours after the beginning of the test, reaching $36 \%$ of repellence. In $0.100 \mathrm{mg} \cdot \mathrm{cm}^{-2}$ concentration,
Table 1. Duration and percentage of repellency of four concentrations of DEET against Amblyomma cajennense nymphs, using fingertip bioassay.

\begin{tabular}{lcccccc}
\hline & \multicolumn{6}{c}{ Repellency \% } \\
$\begin{array}{c}\text { Conc. } \\
\text { mg.cm }\end{array}$ & $\begin{array}{c}\mathbf{1 0} \\
\text { minutes }\end{array}$ & $\mathbf{1}$ hour & 2 hours & $\mathbf{3}$ hours & 4 hours & $\mathbf{5}$ hours \\
\hline & & & & & \\
\hline 0.200 & $100^{\mathrm{a}, \mathrm{A}}$ & $97^{\mathrm{a}, \mathrm{A}}$ & $93^{\mathrm{a}, \mathrm{A}}$ & $100^{\mathrm{a}, \mathrm{A}}$ & $97^{\mathrm{a}, \mathrm{A}}$ & $33^{\mathrm{a}, \mathrm{B}}$ \\
0.100 & $100^{\mathrm{a}, \mathrm{A}}$ & $93^{\mathrm{a}, \mathrm{A}}$ & $67^{\mathrm{b}, \mathrm{B}}$ & $43^{\mathrm{b}, \mathrm{B}}$ & - & - \\
0.050 & $97^{\mathrm{a}, \mathrm{A}}$ & $67^{\mathrm{b}, \mathrm{B}}$ & $0^{\mathrm{c}, \mathrm{C}}$ & - & - & - \\
0.025 & $90^{\mathrm{a}, \mathrm{A}}$ & $40^{\mathrm{c}, \mathrm{B}}$ & $0^{\mathrm{c}, \mathrm{C}}$ & - & - & - \\
Control & $0^{\mathrm{b}}$ & $0^{\mathrm{d}}$ & $0^{\mathrm{c}}$ & $0^{\mathrm{c}}$ & $0^{\mathrm{b}}$ & $0^{\mathrm{b}}$ \\
\hline
\end{tabular}

Different lower-case letters between concentrations and capital letters between repellency duration indicate significant difference by chi-square test $(\mathrm{p}<0.05)$.

- These tests were not done because repellence at previous concentration was lower than $50 \%$

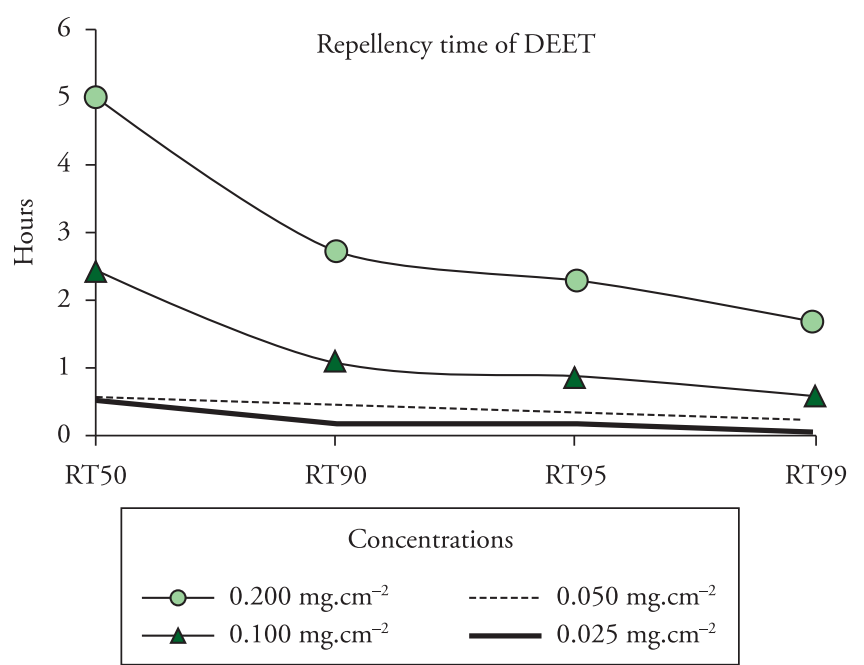

Figure 1. Repellency time of 50, 90, 95 and 99\% (RT50, RT90, RT95 and RT99) of Amblyomma cajennense nymphs tested in different concentrations of DEET in a fingertip bioassay.

a statistical difference between the tests was observed 3 hours after the beginning of the test. Higher rates of repellence were observed in filter-paper (80\%) than in fingertip bioassay (43\%) (Table 2).

\section{Discussion}

In the present study $A$. cajennense nymphs were greatly repelled by DEET in all tested concentrations, and more than $90 \%$ of protection was observed during the 10 minutes- 1 hour interval. The $0.200 \mathrm{mg} . \mathrm{cm}^{-2}$ concentration, equivalent to a $7.2 \%$ solution, guaranteed a $95 \%$ repellency over a 4 hours period. In some species such as $A$. americanum (SCHRECK et al., 1995; SOLBERG et al., 1995) and Ixodes scapularis (CARROLL et al., $2005,2007)$ repellency rates similar to those obtained in the present study were observed only in higher concentrations. On the 
Table 2. Duration and percentage of repellency of two DEET concentrations $\left(\mathrm{mg} . \mathrm{cm}^{-2}\right.$ ) against Amblyomma cajennense nymphs using filter-paper and fingertip bioassays.

\begin{tabular}{|c|c|c|c|c|c|}
\hline \multirow{2}{*}{ Duration } & \multicolumn{2}{|c|}{ Fingertip } & \multicolumn{2}{|c|}{ Filter-paper } & \multirow{2}{*}{ Contro } \\
\hline & 0.200 & 0.100 & 0.200 & 0.100 & \\
\hline 10 minutes & $100^{\text {a, } A}$ & $100^{\mathrm{a}, \mathrm{A}}$ & $100^{\text {a, } A}$ & $100^{\text {a, } A}$ & $0^{\text {B }}$ \\
\hline 1 hour & $97^{\mathrm{a}, \mathrm{A}}$ & $93^{\text {a, A, B }}$ & $98^{\mathrm{a}, \mathrm{A}}$ & $84^{\mathrm{b}, \mathrm{B}}$ & $0^{\mathrm{C}}$ \\
\hline 2 hours & $93^{\mathrm{a}, \mathrm{A}}$ & $67^{b, B}$ & $98^{\mathrm{a}, \mathrm{A}}$ & $70^{\mathrm{b}, \mathrm{B}}$ & $0^{\mathrm{C}}$ \\
\hline 3 hours & $100^{\mathrm{a}, \mathrm{A}}$ & $43^{\mathrm{b}, \mathrm{C}}$ & $98^{\mathrm{a}, \mathrm{A}}$ & $80^{\mathrm{b}, \mathrm{B}}$ & $0^{\mathrm{D}}$ \\
\hline 4 hours & $97^{\mathrm{a}, \mathrm{A}}$ & - & $100^{\mathrm{a}, \mathrm{A}}$ & - & $0^{\mathrm{B}}$ \\
\hline 5 hours & $33^{\mathrm{b}, \mathrm{B}}$ & - & $100^{\mathrm{a}, \mathrm{A}}$ & - & $0^{\mathrm{C}}$ \\
\hline 6 hours & & & $100^{\mathrm{a}, \mathrm{A}}$ & & $0^{\mathrm{B}}$ \\
\hline 20 hours & - & - & $36^{\mathrm{b}, \mathrm{A}}$ & - & $0^{\mathrm{B}}$ \\
\hline
\end{tabular}

Different lower-case letters between repellency duration and capital letters between concentrations indicate significant difference by chi-square test $(\mathrm{p}<0.05)$.

- These tests were not done because repellency at previous concentration was lower than $50 \%$

other hand, protections of similar magnitude were not obtained against $I$. ricinus (STAUB et al., 2002) in field tests or $A$. hebraeum (PRETORIUS et al., 2003) in fingertip bioassay, even using higher concentrations. Salafsky et al. (2000) observed only partial repellency of $A$. americanum adults using commercial 20\% DEET formulations and no protection against Dermacentor variabilis Say. The compound did not repel Amblyomma variegatum Fabricius adults when released with an attractant stimulus (MCMAHON et al., 2003). Based on the results of the present study and on the literature it is clear that $A$. cajennense is more sensitive to DEET than other tick species so far evaluated.

The ECs values observed in the present study reinforce the aforementioned results regarding the high sensitivity of A. cajennense to the compound, considering that they were lower than those obtained by Carroll et al. (2004) to I. scapularis and $A$. americanum, using filter-paper bioassay. When using the fingertip bioassay, Carroll et al. (2007) found ECs to I. scapularis close to the present study and did not find any repellent activity against $A$. americanum.

It was observed that the increase of DEET concentration did not interfere with the initial repellency rate, but increased significantly the repellent time. Similar results were observed by Carroll et al. (2005), testing DEET against $I$. scapularis and $A$. americanum in relation to the initial repellency rate, and by Fradin and Day (2002) when testing DEET against the mosquito Aedes aegypti Linnaeus in relation to repellency time.

The largest increase in repellency duration was observed when the concentration was augmented from 0.100 to $0.200 \mathrm{mg} \cdot \mathrm{cm}^{-2}$; lengthening the protection from 1 to 4 hours, RT90 similar to that obtained here, 2.7 hours at $0.200 \mathrm{mg} \cdot \mathrm{cm}^{-2}$ concentration, was observed by Schreck et al. (1995) in A. americanum, although using a higher concentration of $0.300 \mathrm{mg} \cdot \mathrm{cm}^{-2}$. Against $A$. hebraeum, lower RTs were observed by Pretorius et al. (2003), who obtained 2 hours protection using a 20\% DEET commercial formulation, and by Jensenius et al. (2005), who verified protection against $90 \%$ of ticks for a interval lower than $1 \mathrm{~h}$ using DEET in concentrations as high as $80 \%$. While Fradin and Day (2002) observed more than 5 hours of total protection using a $23.8 \%$ formulation against
A. aegypti, Chou et al. (1997) found high repellency efficacy for 8 hours utilizing formulations with $95 \%$ of DEET. Mathematic models of efficacy and persistence of repellents in mosquitoes show that the protection conferred by DEET is proportional to the logarithm of its concentration, with the higher concentrations promoting longer protection (RUTLEDGE et al., 1985). However, this curve reaches a plateau at the $50 \%$ concentration, and additional protection supplied is lower with each increase of the dose (BUESCHER et al., 1982). The highest concentration used here is lower than those used in the aforementioned studies and even lower than the plateau set up by Buescher et al. (1982). The American Association of Pediatrics recommends the use of DEET between 10 and 30\% concentration for children (AAP COMMITTEE ON ENVIRONMENTAL HEALTH, 2003). This dose can guarantee lasting protection avoiding intoxication, as children are more sensitive to DEET. Therefore there is a potential use of DEET to protect against $A$. cajennense, as it is possible to increase the concentration and, consequently, the repellency duration, with no hazard to human health.

The neurotoxic effects such as locomotor alterations and death after exposure to DEET were described for other arthropods (LICCIARDI et al., 2006), but as far as we know, they are reported for ticks for the first time. Salafsky et al. (2000) observed high mortality of $A$. americanum and $D$. variabilis when exposed to LIPODEET, a long-lasting action formulation of DEET, but it was not proved for DEET.

Similar high rates of repellency were observed in both bioassays. However, nymphs were repelled for a longer time in filter-paper than in fingertip bioassay. Those results are easily explained, as fingertip bioassay is a more rigorous test than filter-paper, because the ticks are more motivated to climb an attractive substrate such as a finger than a piece of filter-paper. Due to the low motivation to climb a piece of paper, this kind of bioassay has the disadvantage of not filtering weak repellents (DAUTEL, 2004). The host skin possesses characteristics that interfere with the efficacy and duration of the repellent activity of a compound; these include: high temperature, transpiration, skin absorption and substances that can combine with repellent molecules. Those factors can contribute to a faster loss of repellency in compounds tested on skin than on paper (MAIBACH et al., 1974).

Based on the results, it is possible to conclude that DEET is an effective repellent against $A$. cajennense nymphs and can be adopted as a reference for future evaluations of compounds for candidates as repellents and for individual protection. Both bioassays, fingertip and filter-paper, are suitable for evaluation of repellency in this species, as the behavior pattern is similar in both. However, for effective concentration and repellence duration estimations, fingertip is more appropriate, as it is a more rigorous test and consequently closer to reality.

DEET has a remarkable safety profile after 40 years of use, and DEET-based repellents remain the gold standard of human protection under circumstances in which it is crucial to be protected against arthropod bites that might transmit disease (FRADIN, 1998). The observation of repellent efficacy of this compound at low concentrations against $A$. cajennense nymphs allows its use as part of a strategy to prevent spotted fever in Central and South America, where $A$. cajennense is the main vector of $R$. rickettsii. 


\section{Acknowledgments}

We thank the National Council of Technological and Scientific Development (CNPq) for its financial support of this project.

\section{Commitee of Ethics}

The use of the animals and the participation of human beings were approved by the Research Ethics Committee from UFG (protocol no11 05/03/2007). The studies with animals were carried out in accordance with ethical norms.

\section{References}

AMERICAN ACADEMY OF PEDIATRICS - AAP. Follow safety precautions when using DEET on children. Elk Grove Village, 2003. Disponível em: $<$ http://aapnews.aappublications.org/cgi/content/full/e200399v1>. Acesso em 07 de setembro de 2008 .

AGÊNCIA NACIONAL DE VIGILÂNCIA SANITÁRIA - ANVISA. Utilizaçáo do DEET em preparaçóes de repelentes para insetos. Brasília, 2006. (Parecer técnico, 2)Disponível em: <http://www.anvisa.gov.br/cosmeticos/informa/ parecer_deet.htm>. Acesso em: 15 de novembro de 2008.

BARNARD, D. R. Global Collaboration for Development of Pesticides for Public Health: GCDPP. Switzerland: World Health Organization, 2000. Disponível em: <http://www.cepis.ops-oms.org/bvsapud/i/fulltext/repellent/ repellent.pdf>. Acesso em: 24 de abril de 2008

BARROS-BATTESTI, D. M.; ARZUA, M.; BECHARA, G. H. Carrapatos de importância médico-veterinária da regiáo neotropical: um guia ilustrado para identificaçấo das espécies. São Paulo: Vox, 2006. 223 p. (v. 1)

BILLINGS, A. N. et al. Detection of a spotted fever group rickettsia in Amblyomma cajennense (Acari: Ixodidae) in south Texas. Journal Medical Entomology, v. 35, n. 4, p. 474-8, 1998 .

BITTENCOURT, V. R. E. P.; MASSARD, C. L.; GRISI, L. Avaliaçấo do efeito carrapaticida de alguns piretróides sintéticos sobre o Amblyomma cajennense (Fabricius, 1787). Hora Veterinária, v. 7, n. 40, p. 21-26, 1987.

BITTENCOURT, V. R. E. P.; MASSARD, C. L.; GRISI, L. Atividade in vitro de alguns piretróides sintéticos no carrapato Amblyomma cajennense (Fabricius, 1787). Pesquisa Agropecuária Brasileira, v. 24, n. 10, p. 1193-1200, 1989.

BUESCHER, M. D.; RUTLEDGE, L. C.; WIRTZ, R. A. Tests of commercial repellents on human skin against Aedes aegypti. Mosquito News, v. 42, p. 428-433, 1982.

BUSTAMANTE, M. E.; VARELA, G.; MARIOTTE, C. O. Estudios de fiebre manchada en Mexico. Fiebre manchada en la Laguna. Revista del Instituto de Salubridad y Enfermedades Tropicales, v. 7, n. 1, p. 39-49, 1946.

CARROLL, J. F.; KLUN, J. A.; DEBBOUN, M. Repellency of deet and SS220 applied to skin involves olfactory sensing by two species of ticks. Medical and Veterinary Entomology, v. 19, n. 1, p. 101-6, 2005

CARROLL, J. F. et al. Repellency of two terpenoid compounds isolated from Callicarpa americana (Lamiaceae) against Ixodes scapularis and Amblyomma americanum ticks. Experimental and Applied Acarology, v. 41, n. 3, p. 215-24, 2007.

CARROLL, J. F. et al. Comparative activity of deet and AI3-37220 repellents against the ticks Ixodes scapularis and Amblyomma americanum (Acari: Ixodidae) in Laboratory Bioassays. Journal of Medical Entomology, v. 41, n. 2, p. 249-254, 2004.
CHOU, J. T.; ROSSIGNOL, P. A.; AYRES, J. W. Evaluation of commercial insect repellents on human skin against Aedes aegypti (Diptera: Culicidae). Journal of Medical Entomology, v. 34, n. 6, p. 624-630, 1997.

DAUTEL, H. Test systems for tick repellents. International Journal of Medical Microbiology, v. 293, supl. 37, p. 182-8, 2004.

DIAS, E.; MARTINS, A. V. Spotted fever in Brazil: a summary. American Journal of Tropical Medicine and Hygiene, v. 19, n. 2, p. 103-108, 1939.

FRADIN, M. S. Mosquitoes and mosquito repellents: a clinician's guide. Annals of Internal Medicine, v. 128, n. 11, p. 931-40, 1998.

FRADIN, M. S.; DAY, J. F. Comparative efficacy of insect repellents against mosquito bites. New England Journal of Medicine, v. 347, n. 1, p. 13-18, 2002.

GUEDES, E. et al. Detection of Rickettsia rickettsii in the tick Amblyomma cajennense in a new Brazilian spotted fever-endemic area in the state of Minas Gerais. Memórias do Instituto Oswaldo Cruz, v. 100, n. 8, p. 841-5, 2005.

JENSENIUS, M. et al. Repellent efficacy of four commercial DEET lotions against Amblyomma hebraeum (Acari: Ixodidae), the principal vector of Rickettsia africae in southern Africa. Transactions of the Royal Society of Tropical Medicine and Hygiene, v. 99, n. 9, p. 708-711, 2005.

LABRUNA, M. B. et al. Controle estratégico do carrapato Amblyomma cajennense em eqüinos. Ciência Rural, v. 34, n. 1, p. 195-200, 2004.

LICCIARDI, S. et al. Lethal and behavioural effects of three synthetic repellents (DEET, IR3535 and KBR 3023) on Aedes aegypti mosquitoes in laboratory assays. Medical and Veterinary Entomology, v. 20, n. 3, p. 288-93, 2006.

MAIBACH, H. I.; KHAN, A. A.; AKERS, W. A. Use of insect repellents for maximum efficacy. Archives of Dermatology, v. 109, n. 1, p. 32-35, 1974.

MCMAHON, C.; KRÖBER, T.; GUERIN, P. M. In vitro assays for repellents and deterrents for ticks: differing effects of products when tested with attractant or arrestment stimuli. Medical and Veterinary Entomology, v. 17, n. 4 , p. $370-378,2003$.

PADDOCK, C. D. et al. Rickettsia parkeri: a newly recognized cause of spotted fever rickettsiosis in the United States. Clinical Infectious Diseases, v. 38, n. 6, p. $805-11,2004$

PRETORIUS, A. M. et al. Repellent efficacy of DEET and KBR 3023 against Amblyomma hebraeum (Acari: Ixodidae). Journal Medical Entomology, v. 40, n. 2, p. 245-8, 2003.

RODANICHE, E. C. Natural infection of the tick, Amblyomma cajennense with Rickettsia rickettsii in Panama. American Journal of Tropical Medicine and Hygiene, v. 2, n. 4, p. 696-699, 1953.

RUTLEDGE, L. C. et al. Mathematical models of the effectiveness and persistence of mosquito repellents. Journal of American Mosquito Control Association, v. 1, n. 1, p. 56-62, 1985.

SALAFSKY, B. et al. Short report: study on the efficacy of a new long-acting formulation of N, N-diethyl-m-toluamide (DEET) for the prevention of tick attachment. American Journal of Tropical Medicine and Hygiene, v. 62, n. 2, 169-172, 2000

SANGIONI, L. A. et al. Rickettsial infection in animals and Brazilian spotted fever endemicity. Emerging Infectious Diseases, v. 11, n. 2, p. 265-70, 2005.

SCHRECK, C. E.; FISH, D.; MCGOVERN, T. P. Activity of repellents applied to skin for protection against Amblyomma americanum and Ixodes scapularis ticks (Acari: Ixodidae). Journal of American Mosquito Control Association, v. 11, n. 1 , p. $136-40,1995$.

SOLBERG, V. B. et al. Field evaluation of deet and a piperidine repellent (AI337220) against Amblyomma americanum (Acari: Ixodidae). Journal Medical Entomology, v. 32, n. 6, p. 870-5, 1995.

SONENSHINE, D. E. Biology of ticks. New York: Oxford University Press, 1991. 447 p. (v. 1)

STAUB, D. et al. Effectiveness of a repellent containing DEET and EBAAP for preventing tick bites. Wilderness and Environmental Medicine, v. 13, n. 1, p. 12-20, 2002 